\title{
OVARIAN DEVELOPMENT IN THE AMAZONIAN RED DISCUS, Symphysodon discus HECKEL (OSTEICHTHYES: CICHLIDAE)
}

\author{
CHELLAPPA, S. ${ }^{1}$, CÂMARA, M. R. ${ }^{2}$ and VERANI, J. R. ${ }^{2}$ \\ ${ }^{1}$ Post-Graduate Program in Aquatic Bioecology, Department of Oceanography and Limnology, Center of Biosciences, \\ Federal University of Rio Grande do Norte, Praia de Mãe Luíza, s/n, CEP 59014-100, Natal, RN, Brazil \\ ${ }^{2}$ Post-Graduate Program in Ecology and Natural Resources, Federal University of São Carlos, \\ Via Washington Luiz, Km 235, Caixa Postal 676, CEP 13565-905, São Carlos, SP, Brazil \\ Correspondence to: Sathyabama Chellappa, Department of Oceanography and Limnology, Center of Biosciences, \\ Federal University of Rio Grande do Norte, Praia de Mãe Luíza, s/n, CEP 59014-100, Natal, RN, Brazil \\ e-mail: bama@dol.ufrn.br
}

Received March 2, 2004 - Accepted June 25, 2004 - Distributed November 30, 2005

(With 2 figures)

\begin{abstract}
The Neotropical red discus fish, Symphysodon discus, originates from the Amazonian basin and has a discoid body. Although this species is popularly used in aquaria and is exported as an ornamental fish, it has not been intensively studied. The purpose of this work was to study the morphological and histological aspects of the ovarian development in the red discus. Forty females of $S$. discus of varying body sizes and different stages of gonadal development were used in this study. The ovaries were weighed and examined macroscopically in order to observe the maturation stages. Histological staining of hematoxilin-eosin was used for microscopic observations of the ovaries. Macroscopic observations showed immature, maturing, mature and partially spent stages of ovarian development. Microscopic examination of the ovaries revealed five stages and five phases of ovarian development. The ovaries of the mature females showed all the different phases of oocyte development, indicating the multiple spawning habit of this species.
\end{abstract}

Keywords: Symphysodon discus, amazonian fish, Cichlidae, gonadal development.

\section{RESUMO}

\section{Desenvolvimento ovariano do Acará Disco Amazônico, Symphysodon discus Heckel (Osteichthyes: Cichlidae)}

O acará disco, Symphysodon discus, é um ciclídeo neotropical originário da bacia Amazônica e seu corpo apresenta formato discoidal. Embora esta espécie seja popularmente utilizada em aquariofilia e exportada como peixe ornamental, ainda é pouco estudada. Este trabalho teve como objetivo estudar os aspectos morfológicos e histológicos do desenvolvimento ovariano do acará disco. Para este estudo foram utilizadas 40 fêmeas de $S$. discus, de tamanhos diferentes, em várias fases de desenvolvimento gonadal. Os ovários foram pesados e examinados macroscopicamente para observar os estádios de maturação. Para as observações microscópicas dos ovários foi utilizada coloração de hematoxilina-eosina. Os resultados da análise macroscópica apresentaram os estádios de desenvolvimento ovariano imaturo, em maturação, maduro e parcialmente esvaziado. A análise microscópica dos ovários revelou cinco estádios e cinco fases de desenvolvimento ovariano. Os ovários das fêmeas maduras apresentaram todas as diferentes fases de desenvolvimento ovocitário, indicando a desova múltipla para a espécie estudada.

Palavras-chave: Symphysodon discus, peixe amazônico, Cichlidae, desenvolvimento ovariano. 


\section{INTRODUCTION}

The family Cichlidae (Order: Perciformes; Class: Osteichthyes) consists of about 105 genera with 1300 species of freshwater and estuarine fishes (Keenleyside, 1991; Meijide \& Guerrero, 1997). Cichlids have a wide geographical distribution and are natives of Africa (with 900 valid species and more than 1300 estimated species), South America (with 290 valid species), Central America (Cuba and Hispania, with 4 valid species including some estuarine species), North and Central America (with 95 valid species), Asia (Southern India and Sri Lanka, with 3 estuarine species), Madagascar (with 17 valid species, some estuarine species), Middle East (Jordan, with 4 species), Iran (one species) and several regions of the USA (Kullander, 1998).

Kullander (1998) estimated that there are 290 valid species of cichlids in South America and 95 species in Central America. Lowe-McConnell (1999) estimated around 400 species of Neotropical cichlids grouped in 50 genera. The Neotropical cichlids of South America are well represented in the Amazonian/Guyanean region, in the Orinoco region to the north and in the Paranean region to the south, besides the rivers in eastern Brazil (Keenleyside, 1991; Lowe-McConnell, 1991; Kullander, 1997).

The Amazon basin includes an extensive region covered by dense rain forest, an area exceeding $2.5 \times 106 \mathrm{~km}^{2}$, lying less than $200 \mathrm{~m}$ above sea level. This complex basin forms a heterogeneous environment, including lateral lakes on the floodplain, nutrient-rich white water rivers and nutrient-poor black water rivers. There are also clear water rivers and rain forest rivers and this region has a rainfall of $3000 \mathrm{~mm}$. The cichlids of the Amazon basin share its biotopes with noncichlid species (Keenleyside, 1991).

The red discus, Symphysodon discus Heckel, 1840 is a Neotropical cichlid which originates from the igarapes (streams) of the Amazonian basin, restricted to the lower regions of the Negro, Abacaxis and Trombetas rivers. S. discus lives mainly in clean and tranquil waters and is a slow swimmer. This cichlid species belongs to the Order Perciformes and to the Heroini lineage (Kullander, 1998). Its commercial importance lies in its extensive use in aquaria and exportation as an ornamental fish (Ferraz, 1999).

This species is strikingly unlike the other cichlids due to its discoidal and laterally compressed body form (Câmara et al., 2002). Its reproductive behavior is complex, involving competition for territory and mates, courtship and parental care. The males establish breeding territories utilizing aquatic plants with wide leaves, to which the females are attracted. Males defending territories are more aggressive and gain priority in courting females. Courtship provides an opportunity for mate choice and also fulfils several mutually compatible functions, such as orientation to the spawning site and synchronization of the spawning activities, so that gametes are released at the same time (Câmara \& Chellappa, 2002).

Ornamental fish culture is gaining popularity and hence there is a growing need for information on the ecology, diet, behavior and reproduction of these fish. Although the Neotropical cichlids are very popular ornamental fish, scientific information about their gonadal development and reproduction is very limited, as in the case of the angel fish, Pterophyllum scalare (Dias \& Chellappa, 2003).

The reproductive process is an essential part of the study the biology of species (Silva \& Esper, 1991). Fishes exhibit the whole spectrum of life history strategies in relation to spawning frequency. In contrast with the semelparous species, which spawn once in their life span, different spawning modes occur in the iteroparous species. Some species spawn once a year for several years, as in total spawners, whereas others spawn several batches within an annual cycle, as in multiple or partial spawners (Wootton, 1990; Rinchard \& Kestmont, 1996). As such, an understanding of the gonadal development and reproductive cycles of fishes is of fundamental importance for the conservation of natural stocks and for fish culture purposes.

Various phases of gonadal development of fishes have been studied to clarify the dynamics and regulation of oogenesis (Potts \& Wootton, 1984). Sex determination is possible only by examining the gonads of fish species that do not present any apparent sexual dimorphism, as in the case of $S$. discus. Macroscopic characteristics of the gonads involve the size, coloration, degree of vascularization and appearance of the oocyte 
clusters. However, such observations alone are insufficient to clarify the dynamics and regulation of oogenesis. Hence, the histological study of the gonads is of vital importance.

This paper reports on the morphological and histological aspects of the ovarian development in the Amazonian red discus, S. discus.

\section{MATERIAL AND METHODS}

\section{Study area and sample collection}

Female fishes of Symphysodon discus (Fig. 1) used in this study were collected, with the help of the local fisherman, from the igarapes of the Negro River of the Amazon basin. Forty females of $S$. discus of different sizes were used and the sample size was sufficiently large to allow the various biometric and histological variables to be accurately estimated without depleting the natural population.

This study was conducted from April 2002 to July 2003 in the Ichthyology Laboratory of the Department of Oceanography and Limnology, Federal University of Rio Grande do Norte, Natal, $\mathrm{RN}$, Brazil. The fishes were weighed (Quimis Semi-analítica, Modelo QI-3000, precision $\pm 1 \mathrm{~g}$ ) and their total lengths determined $( \pm 1 \mathrm{~mm})$. They were then dissected, sexed and the location and general appearance of the ovaries were recorded. Both ovaries were removed and weighed (SAUTER, Model D-7470, precision $\pm 0.1 \mathrm{mg}$ ). The gonadosomatic index (GSI) was used to assess the reproductive status (Wooton et al., 1978). GSI $=100$ (wet wt of gonads in g) / (total body wet wt in g).

\section{Ovarian analysis}

To avoid possible variations in the developmental stages of oocytes due to their position in the ovaries, histological examinations were carried out on sections from the anterior (cephalic), middle (central), and posterior (caudal) regions of both ovaries. The ovaries were preserved in Bouin's solution and, after $24 \mathrm{~h}$, were transferred to $50 \%$ ethanol. The preserved ovaries were embedded in paraffin, sectioned into $10 \mu \mathrm{m}$ thick slices, and stained with hematoxylin and eosin (Michalany, 1990). Three slides were prepared from different parts of each ovary of each of the 40 fish to determine if oocyte development was consistent along the length of the ovary. Ovarian developmental stages were assessed microscopically with the help of a light microscope (Taimin, model TM 800) coupled to a video camera (Kodo Digital). In addition, the relative frequency of the different sizes of oocyte was estimated by enumerating a subsample of the different sized oocytes of each ovary (West, 1990).

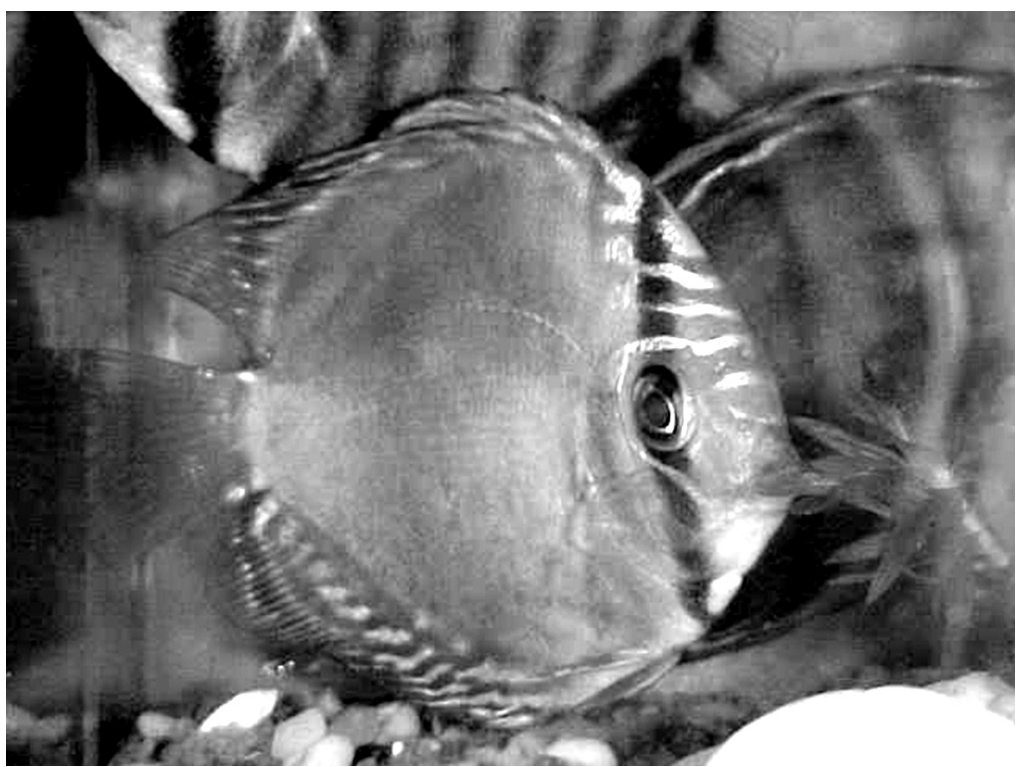

Fig. 1 - Red discus, Symphysodon discus Heckel, 1840. 
The diameters of oocytes from all the ovaries were measured with an ocular micrometer.

The terminology used for staging the individual oocytes based on their histological appearance was adapted from Palmer et al. (1995) and Vazzoler (1996).

\section{RESULTS}

\section{Length, weight and GSI of females}

Female fishes up to an average total length of $130.87 \mathrm{~mm}( \pm$ SD 8.11$)$ and an average total weight of $136.52 \mathrm{~g} \mathrm{(} \pm$ SD 16.00) were immature and presented a low mean GSI (0.02) value. Females having an average total length of $134.44 \mathrm{~mm}( \pm$ SD 6.41) and an average total weight of $134.06 \mathrm{~g}( \pm 35.14)$ were maturing and showed a slightly higher mean value of GSI (0.06). The mature females with ripe oocytes had an average total length of $134.00 \mathrm{~mm}$ $( \pm$ SD 0.01$)$ and an average total weight of $167.50 \mathrm{~g}$ ( \pm 2.40 ), and presented a high GSI (0.10). The partially spent females presented low GSI values (0.01) although they were larger, with an average total length of $139.00 \mathrm{~mm}( \pm$ SD 0.01$)$ and an average total weight of $155.70 \mathrm{~g}( \pm 0.01)$. Table 1 shows the average values of total length and weight, and the GSI values of females in different stages of ovarian development.

\section{Ovarian macroscopic characteristics}

The macroscopic observations showed the ovary as a long and fusiform-paired organ situated in the posterior-dorsal part of the celomic cavity, ventral to the kidneys and the swim bladder, to which it was attached by the mesovary originating from the peritoneum. The mesovary is covered with a thin capsule of fibrous conjunctive tissue, the albugine tunica, which internally separates the ovigerous lamella. The ovaries are free in the anterior region, but are united in the posterior region, forming the short oviduct, which opens into the urogenital papilla beyond the anus. The left and right ovaries of the red discus were symmetrical in size. The macroscopic observations of the ovaries of $S$. discus showed four stages of ovarian development, as described in Table 2.

\section{Ovarian microscopic characteristics}

Microscopic examination of histological sections of ovaries revealed five stages of ovarian

TABLE 1

Total length (Lt), total weight $(\mathrm{Wt})$, Stage of gonadal maturity and Gonadosomatic Index (GSI) of the females of red discus, S. discus.

\begin{tabular}{|c|c|c|c|}
\hline $\mathbf{L t}(\mathbf{m m})(\mathbf{x} \pm \mathbf{S D})$ & $\mathbf{W t}(\mathbf{g})(\mathbf{x} \pm \mathbf{S D})$ & Stage of gonadal maturity & $\mathbf{G S I}(\mathbf{x} \pm \mathbf{S D})$ \\
\hline $130.87 \pm 8.11$ & $136.52 \pm 16.00$ & Immature & $0.02 \pm 0.02$ \\
\hline $134.44 \pm 6.41$ & $134.06 \pm 35.14$ & Maturing & $0.06 \pm 0.02$ \\
\hline $134.00 \pm 0.01$ & $167.50 \pm 2.40$ & Mature & $0.10 \pm 0.01$ \\
\hline $139.00 \pm 0.01$ & $155.70 \pm 0.01$ & Partially Spent & $0.01 \pm 0.01$ \\
\hline
\end{tabular}

TABLE 2

Macroscopic characteristics of the ovarian developmental stages in S. discus.

\begin{tabular}{|c|l|}
\hline Stage of maturation & \multicolumn{1}{c|}{ Description } \\
\hline Immature & $\begin{array}{l}\text { The ovaries of young females are small, occupying less than } 1 / 3 \text { of the coelomic cavity, } \\
\text { thread-like, translucent, light yellow, with superficial blood vascularization. Oocytes were } \\
\text { not visible to the naked eye. }\end{array}$ \\
\hline Maturing & $\begin{array}{l}\text { The ovaries are larger, occupying about } 1 / 3 \text { of the coelomic cavity, varying from yellow to } \\
\text { pinkish-orange, and intensely vascularized. Small opaque oocytes were visible to the naked eye. }\end{array}$ \\
\hline Mature & $\begin{array}{l}\text { The ovaries occupy } 1 / 2 \text { of the coelomic cavity. Oocytes become larger as the development } \\
\text { proceeds, taking on a dark yellow hue resulting from the accumulation of yolk granules. } \\
\text { Numerous larger opaque oocytes with intense superficial vascularization were observed. }\end{array}$ \\
\hline Partially Spent & The ovaries were rather flaccid, occupying about half of the coelomic cavity. \\
\hline
\end{tabular}


development and five phases of oocyte development. The oocyte diameter varied, according to the various stages of development, from $100 \mu \mathrm{m}$ to $1000 \mu \mathrm{m}$. According to the frequency distribution of the oocyte diameters, they were grouped into four different size categories ( 0 to $250 \mu \mathrm{m}, 251$ to $500 \mu \mathrm{m}, 501$ to $750 \mu \mathrm{m}$ and 751 to $1000 \mu \mathrm{m}$ ). The oocyte development was consistent along the entire length of the ovary, depending on the degree of ovarian maturation.

\section{Stage I - Immature}

During the first growth stage, young germ cells compactly filled the ovaries of young females (Fig. 2a). The oocyte showed a well-defined spherical nucleus with clear nucleoplasm, thin filaments of chromatic material, and sometimes contained two or more nucleoli. As the oocyte grew, the initially clear cytoplasm acquired a basophilic nature, which became accentuated with the development of the cell. The occurrence of young germ cells was observed (Phase I), along with the reserve stock of oocytes (Phase II).

Phase I - Chromatin nucleolar phase: The small oocytes of germ lineage were found embedded in follicular tissue as a result of ovogonial differentiation. Clusters of oocytes were found lying just beneath the ovigerous lamella, and had a large nucleus occupying the greater part of the oocyte. One or more nucleoli were observed within the nucleus. The nucleus showed little affinity to stains in comparison with the cytoplasm. The immature oocytes had basophilic cytoplasm and were characterized by the total absence of yolk. A fine layer of conjunctive tissue surrounded the oocytes.

Phase II - Perinucleolar phase: Oocyte size increased and was more voluminous with basophilic cytoplasm (Fig. 2b). Multiple nucleoli were distributed around the inner part of the nuclear envelope. Follicular cells surrounded the oocytes in the form of a single layer.

The ovaries of maturing females showed two distinct stages: maturing I and maturing II.

\section{Stage II - Maturing}

This stage began from the time the oocytes became visible to the naked eye. The ovaries were small, translucent and orangy-pink. As the oocytes developed, their color gradually turned reddish-pink, and at times even yellow. Maturing was characterized by the presence of stock reserve oocytes (Phase II), as well as oocytes with lipid droplets and cortical alveoli (Phase III). Germ cells and ovigerous lamellae, which form the basic structure of ovaries, were observed in all the stages.

The oocytes in maturation were characterized by the presence of cortical alveoli. They appeared initially in the peripheral region of the oocyte, while simultaneously occurring in isolation. The cytoplasm gradually lost its basophile.

Phase III - The cortical alveoli phase: This phase was characterized by the presence of large round cells, voluminous nuclei and granular cytoplasm, with the appearance of cortical alveoli in the periphery. The cytoplasm showed the presence of lipid droplets. The follicular layer showed an external surface with cells flatter than the theca.

The end stage was characterized by the larger diameter of the oocytes due to the presence of lipid droplets and protein (Phase IV). Yolk granules and oil vesicles were distributed in the cytoplasm. The yolk granules began to appear initially in the peripheral region of the cell as small bodies with an affinity to stains. These granules increased in number and size, becoming ovoid and gradually moving to the periphery of the cytoplasm, in the direction of the irregular nucleus. The nucleoli were still observed. In this stage, the zona radiata appeared, initially thin, with radiating lines developing as the oocyte matured (Figs. 2c and 2d).

Phase IV - Early yolk phase: In this phase the nucleus was still in the center and had an irregular outer surface, numerous nucleoli presenting larger cells, and the cytoplasm was filled with yolk granules. The follicle was composed of the zona radiata, followed by the granulosa in a single layer of cells.

\section{Stage III - Mature}

Mature females had swollen ovaries that occupied half of the body cavity and had numerous large oocytes as well as smaller ones. The color was dark yellow due to the deposition of large quantities of yolk. The mature oocytes were full of yolk plates and showed nuclear migration close to the micropyle region.

The surrounding layers were fully developed. The mature oocytes were transformed from rounded to polyhedral shapes as a result of a mutual 


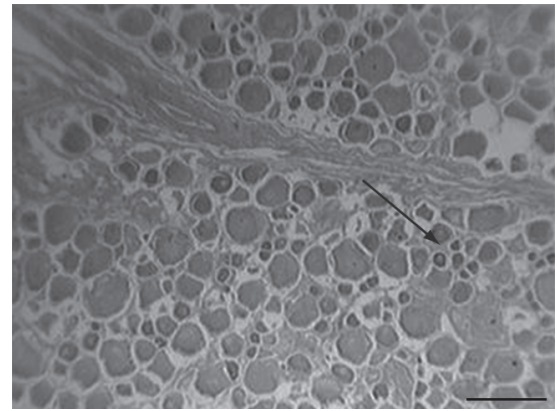

(a)

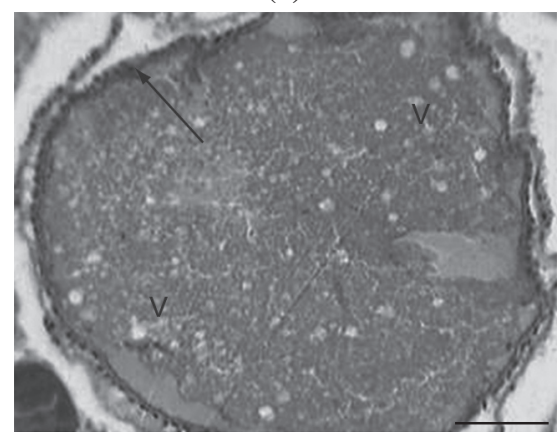

(c)

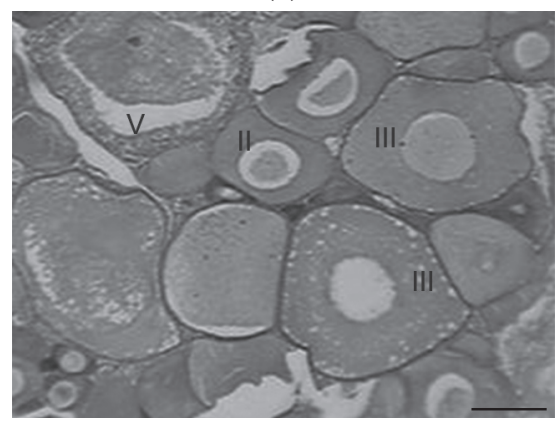

(e)

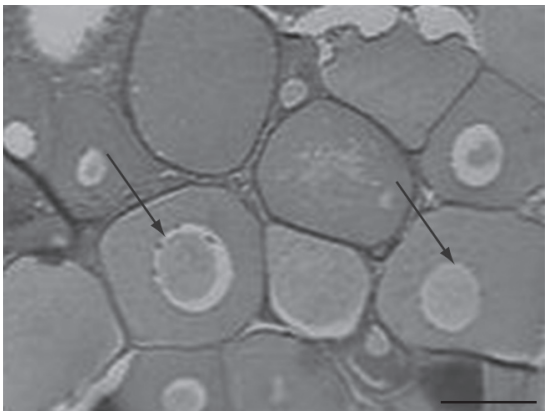

(b)

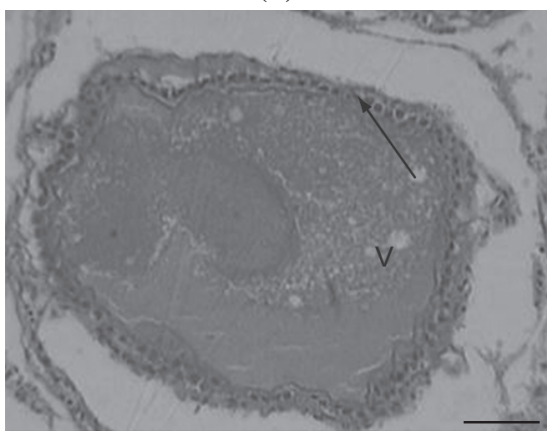

(d)

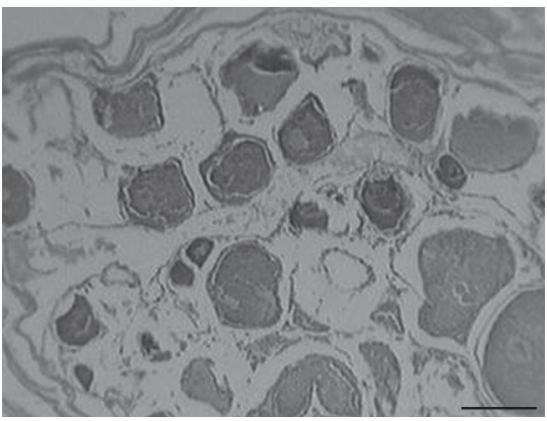

(f)

Fig. 2 - Histological sections showing the ovarian development of Symphysodon discus a) Ovary in the immature stage, showing young germ cells (arrow) (scale bar $100 \mu \mathrm{m}$ ); b) Oocytes in the immature stage, with multiple nucleoli within the nucleus (arrow) (scale bar $200 \mu \mathrm{m}$ ); c) and d) Oocytes in the maturation stage, showing yolk granules (v) and zona radiata (arrow) (scale bar $200 \mu \mathrm{m}$ ); e) Ovary in the partially spent stage, showing oocytes in various phases of development: perinucleolar phase (II), cortical alveoli phase (III) and oocyte in atresia (V) (scale bar $500 \mu \mathrm{m}$ ); and f) Ovary in the partially spent stage, showing empty follicles (scale bar $200 \mu \mathrm{m}$ ), immature and maturing oocytes. (Stained by Hematoxylin-eosin).

compression effect. In addition to the large quantity of mature oocytes, oocytes were also present in the other phases of development, such as immature and maturation, besides the reserve stock of oocytes.

Phase V - Mature oocyte: This phase showed the largest cells of the germ lineage. Numerous yolk granules fused into yolk plates and oil vesicles fused into oil droplets. The yolk granules gave the cytoplasm of the oocyte a grainy appearance. Flat cells formed the theca. The zona radiata and the zona granulosa were observed. The oocytes were retained in this stage before completing final maturation.

\section{Stage IV - Ripening}

In the mature stage the oocytes were mainly in various stages of development (Phases I to V) with an abundance of oocytes in Phase V. Among the oocytes in the final maturation phase, the nucleus of those in the most advanced stage moved toward the micropyle region of the animal pole. These 
oocytes were ready for release. The mature females showed the simultaneous occurrence of oocytes of different sizes, indicating that each individual of S. discus spawns more than once within a breeding cycle (Fig. 2e).

\section{Stage V-Partially spent}

The ovaries of partially spent females appeared somewhat flaccid with some haemorrhaging areas and empty spaces. Only few small oocytes were present in the ovaries of partially spent females, besides some oocytes in maturation stage. Postovulatory follicles, residual oocytes in the reabsorbing process of atresia, and immature and maturing oocytes characterized the partially spent stage (Fig. 2f). Atretic oocytes were recognized by their irregular shape, disintegration of the nucleus and liquefaction of yolk granules.

\section{DISCUSSION}

The general morphology and microscopic examination of histological sections of ovaries of the red discus, $S$. discus, indicates that it resembles that of the majority of teleost fishes. The left and right ovaries of the red discus were symmetrical in size, as observed in other cichlids such as the angelfish, Pterophyllum scalare (Dias \& Chellappa, 2003), and Cichla monoculus (Chellappa et al., 2003). The macroscopic classification of the ovaries of the red discus suggests that there is a regular pattern of ovarian development in each stage of maturity, i.e., the immature, maturation, mature and partially spent stages. These findings are consistent with those of red hybrid tilapia, Oreochromis niloticus $\mathrm{X}$ O. mossambicus (Câmara \& Chellappa, 2000) and of Cichla monoculus (Câmara et al., 2002, 2003).

Dias et al. (1998) discussed possible omissions of the various gonadal developmental stages due to macroscopic analyses and emphasized the importance of histological studies involving microscopic observations in order to correct such omissions, since macroscopic analyses of gonads provide only gross information and may involve errors and omissions. Our macroscopic analyses of the ovaries revealed four developmental stages of $S$. discus, i.e., immature, maturing, mature and partially spent. The microscopic analyses enabled us possible to identify five stages of ovarian development involving five phases. These were phases I and II (corresponding to the immature stage of development), phases III and IV (corresponding to the maturing stage), and phase $\mathrm{V}$ (corresponding to the mature stage), ripening stage and the partially spent stage with some empty follicles, mature oocytes in re-absorption, and large numbers of immature and maturing oocytes.

Ovaries of $S$. discus in the immature stage were characterized by the occurrence of young germinative cells and ovogonia, whereas the ovaries in maturation showed young and maturing oocytes in the ovigerous lamellae. Barbieri et al. (1981) observed a similar pattern for another cichlid, Geophagus brasiliensis.

The present study on S. discus found that the mature female simultaneously contains oocytes of varying sizes in every developmental stage, which is typical of a multiple spawner. Other cichlids, such as the red hybrid tilapia, Oreochromis niloticus $\times O$. mossambicus (Câmara \& Chellappa, 2000), Cichla monoculus (Câmara et al., 2003) and the angelfish, Pterophyllum scalare (Dias \& Chellappa, 2003) also display partial spawning and spawn more than once within a breeding cycle.

Multiple spawners are characterized by the temporal pattern of macroscopic ovarian stages, the regular occurrence of partially spent ovaries, and the oocyte development pattern, with the release of mature oocytes in batches, as in the case of Cichla monoculus (Chellappa et al., 2003). The multiple spawning pattern of red discus can be represented by an inner cycle (composed of ovulation, spawning and redevelopment) within the general reproductive cycle. The inner cycle continues throughout the spawning season. Due to the multiple spawning pattern of red discus, the GSI does not clearly indicate peak spawning activity.

Acknowledgments - Mércia Rocha da Câmara is grateful to CAPES/MEC (Brazil) for the financial support awarded her during the study period.

\section{REFERENCES}

BARBIERI, M. C.; BARBIERI, G. \& MARINS, M. A., 1981, Sobre a anatomia e histologia de testículo de Geophagus brasiliensis (Quoy \& Gaimard, 1824) na Represa do Lobo, Estado de São Paulo. Revista Brasileira de Biologia, 41(1): 169-173.

CÂMARA, M. R. \& CHELLAPPA, S., 2000, Reprodução nas fêmeas do híbrido vermelho de tilápia, Oreochromis niloticus x Oreochromis mossambicus (Osteichthyes: 
Cichlidae). Revista de Ecologia Aquática Tropical, 10: 77-83.

CÂMARA, M. R. \& CHELLAPPA, S., 2002, Territorialidade em acará disco, Symphysodon discus. In: Anais do XX Encontro Anual de Etologia. São Paulo: Associação Brasileira de Etologia, v.1, 445 p.

CÂMARA, M. R., CHELlAPPA, N. T. \& CHELlAPPA, S., 2002, Ecologia reprodutiva do Cichla monoculus, um ciclídeo amazônico no semi-árido do Rio Grande do Norte. Acta Limnologica Brasiliensia, 14 (2): 9-16.

CÂMARA, M. R., VERANI, J. R., CHELLAPPA, S., 2002, Descrição morfométrica, merística e produção de muco do acará disco, Symphysodon discus Heckel, 1840 (Osteichthyes: Cichlidae). In: Anais do XXIV Congresso Brasileiro de Zoologia. Curitiba: Associação Brasileira de Zoologia, v.1, 319 p.

CHELlAPPA, S., CÂMARA, M. R., CHELLAPPA, N.T., BEVERIDGE, M.C.M. \& HUNTINGFORD, F. A., 2003, Reproductive ecology of a neotropical cichlid fish, Cichla monoculus (Osteichthyes, Cichlidae). Brazilian Journal of Biology, 63 (1): 17-26.

DIAS, R. L. \& CHELLAPPA, S., 2003, Desenvolvimento gonadal do ciclídeo ornamental acará bandeira, Pterophyllum scalare. In: URBINATI, E. C. \& CYRINO, J. E. P. (eds). Anais do XII Simpósio Brasileiro de Aqüicultura. Vol. 2. AQUABIO: Jaboticabal, SP, pp. 135-148.

DIAS, J. F., PERES-RIO E., CHAVES, P. T. C. \& ROSSIWONGTSCHOWSKI, C. L. D. B., 1998, Análise macroscópica dos ovários de teleósteos: problemas de classificação e recomendações de procedimentos. Revista Brasileira de Biologia, 58 (1): 55-69.

FERRAZ, E., 1999, Management and diseases of the ornamental fish exported from the rio Negro basin. In: VAL, A. L. \& ALMEIDA-VAL, V. M. F., (eds). Biology of Tropical Fish. Manaus: INPA, pp. 99-111.

HECKEL, J. J., 1840, Johann Natterer's neue Flussfische Brasilien's nach den Beobachtungen und Mittheilungen des Entdeckers beschrieben (Erste Abtheilung, Die Labroiden). Ann. Wien. Mus. Naturges. p. 325-471.

KEENLEYSIDE, M. H. A., 1991, Cichlid Fishes-Behaviour Ecology and Evolution. London: Chapman and Hall, $377 \mathrm{p}$.

KULLANDER, S. O., 1997, Crenicichla rosemariae, a new species of pike cichlid (Teleostei, Cichlidae) from the upper Rio Xingu drainage, Brazil. Ichthyol. Explor. Freshwat. 7(3): 279-287.
KULLANDER, S. O., 1998, A phylogeny and classification of the South American Cichlidae (Teleostei: Perciformes). p. 461-498. In: L. R. Malabarba, R. E. Reis, R. P. Vari, Z.M. Lucena \& C.A.S. Lucena (eds.) Phylogeny and classification of Neotropical fishes. Porto Alegre, EDIPUCRS, 603 p.

LOWE-MCCONNELL, R. H., 1991, Ecology of cichlids in South American and African waters, excluding the African great lakes. In: M. H. A. KEENLEYSIDE (ed.) Cichlids Fishes Behaviour, Ecology and Evolution. London: Chapman and Hall, pp. 60-85.

LOWE-MCCONNELL, R. H., 1999, Estudos ecológicos de comunidades de peixes tropicais. São Paulo: EDUSP. 534 p.

MEIJIDE, F. J. \& GUERRERO, G. A., 1997, Characterization of the reproductive behaviour and early life history stages of Cichlasoma dimerus (Heckel, 1840) (Perciformes, Cichlidae) under laboratory conditions. In: Proceedings of International Symposium on Phylogeny and Classification of Neotropical Fishes. Porto Alegre: EDIPUCRS, 74 p.

MICHALANY, J., 1990, Técnica histológica em anatomia patológica com instruções para o cirurgião, enfermeiro e citotécnico. Ed. São Paulo: SP, 247 p.

PALMER, E. E., SORENSEN, P. W. \& ADELMAN, I. R., 1995, A histological study of seasonal ovarian development in freshwater drum in the Red Lakes, Minnesota. Journal of Fish Biology, 47: 199-210.

POTTS, G. W. \& WOOTTON, R. J., 1984, Fish reproduction: strategies and tactics. Academic Pres: London, $410 \mathrm{p}$.

RINCHARD, J. \& KESTEMONT, P., 1996, Comparative study of reproductive biology in single and multiple spawner cyprinid fish. 1. Morphological and histological features. Journal of Fish Biology, 49: 883-894.

SILVA, R. M. P. C. \& ESPER, M. L. P., 1991, Observações sobre o desenvolvimento citomorfológico dos ovários de tainha, Mugil platanus (Günther) da Baía de Paranaguá (Brasil). Acta Biologica Paranaense, 20 (1-4): 15-39.

VAZZOLER, A.E. A. M., 1996, Biologia da reprodução de peixes teleósteos: teoria e prática. Maringá: EDUEM, 169 p.

WEST, G., 1990, Methods of assessing ovarian development in Fishes: a review. Australian Journal of Marine and Freshwater Research, 41: 199-222.

WOOTTON, R.J., 1990, Ecology of Teleost Fishes. London: Chapman and Hall, $404 \mathrm{p}$.

WOOTTON, R. J., EVANS, G. W. \& MILLS, L. A., 1978, Annual cycle in female three-spined sticklebacks (Gasterosteus aculeatus) from an upland and lowland population. Journal of Fish Biology, 12: 331-343. 